\title{
Lump-sum Transfers for Agriculture and Household Decision Making
}

\author{
Kate Ambler \\ International Food Policy Research Institute \\ Alan de Brauw \\ International Food Policy Research Institute \\ Susan Godlonton \\ Williams College and International Food Policy Research Institute
}

\begin{abstract}
We study the impact of one-season transfers framed for agricultural investment on smallholders in Senegal and Malawi using data from an RCT in each country. We find suggestive evidence that transfers reduced both the number of decision makers and female decision making in Senegal in the short-run, particularly for measures directly related to agriculture. Effects are gone two years after the transfers. Conversely, transfers in the Malawi program led to robust transitory increases in these measures.
\end{abstract}

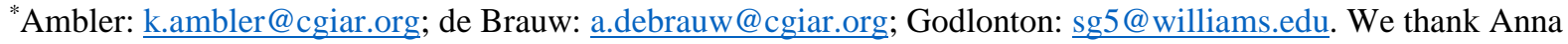
Vanderkooy, Cheng Qiu, Michael Murphy, Phoebe Scollard, Kelvin Balakasi and Misheck Mphande for research assistance. We also thank Alphonse Aflagah, Ian Concannon, Kathy Bi, Naomi Medina-Jaudes, Sean Ninsing, and Shadman Rahman. For field work we thank Samba Mbaye and his team in Senegal and the IPA Malawi team. This project would not have been possible without the support of our partners, including Macadou Gueye, Papa Assane Diop, Ousmane Pouye, Guillaume Bastard, Wycliffe Kumwenda, Frank Masankha, and Henderson Chikanaulanga. The project was primarily funded by DFID Brazil and has also received support from the CGIAR Research Program on Policies, Institutions, and Markets. This study was registered in the AEA RCT registry, study number
} AEARCTR-0000456. 


\section{Introduction}

As transfer programs have gained popularity in the developing world as a tool for improving the livelihoods of poor households, interest has grown in studying the consequences of these programs for the dynamics of decision making within families. This question is important from a number of perspectives. Cash transfers can directly affect bargaining power, which in turn affects how household resources, including transfers, are used. ${ }^{1}$ While bargaining is not directly observable, decision making has been shown to be a good proxy in a number of settings (Lundberg and Pollack 1996; Duflo 2012; Browning, Chiappori, and Weiss 2014). Additionally, women's participation in decision making is seen as an important component of increasing women's empowerment more generally, which is often a primary or secondary goal of many transfer programs. In this paper, we study the impact of one-time, lump sum transfers on a range of household decision-making outcomes in the context of programs for smallholder farmers in Senegal and Malawi.

The programs studied here combine transfers with support services and have the primary goal of improving farmer livelihoods by increasing agricultural production. ${ }^{2}$ Both are evaluated through the use of randomized control trials. The Senegal project included a control group that received monthly advisory visits conducted by an animateur (a farmer from the area trained to implement the program), a group that received those visits and also a farm management plan intended to help the farmers effectively allocate their resources over the year, and a group that received the visits, the plan, and a one-time cash transfer worth approximately USD200. An

\footnotetext{
${ }^{1}$ Examples of models that make this point include Chiappori (1988), Chiappori (1992), Lundberg and Pollack (1993), Lundberg and Pollack (1994), Manser and Brown (1980), McElroy and Horney (1981). See Doss (2013) for a review of the empirical evidence.

${ }^{2}$ See Ambler, de Brauw, and Godlonton (forthcoming and 2018) for results of the primary impact evaluation of these studies.
} 
interesting component of the Senegal program was that one of its explicit goals was to increase family participation in decision making, particularly regarding agricultural activities. We collect data over two years; support services were administered in both years, but the transfers were only given once, at the beginning of year 1. Results from the Senegal study show that the transfers resulted in one-year improvements in crop production, and increased holdings of livestock and agricultural equipment that were sustained over two years. No robust impacts of the management plan alone are identified (Ambler, de Brauw, Godlonton forthcoming).

The Malawi project cross-randomized transfers and support services. The transfer treatment included a control group, a group that received a series of three cash transfers over one season, and a group that received a series of three input transfers over the same season. The cash transfers were given at planting $(\$ 36)$, mid-season $(\$ 22)$, and harvest $(\$ 26)$. The input transfers were given on the same schedule, were of equivalent value, and approximately 50 percent of the value was given in kind in the form of seed, hoes, inoculant, and storage sacks. The support services were administered in a cross-randomized treatment that included a control group receiving only standard services offered by our partner, and a treatment group that received intensive technical advice and a farm management plan from a trained extension worker. As in Senegal, the transfers were given only in the first year, and support services continued for two years. In Malawi the allocation of support services was re-randomized in the second year.

In Ambler, de Brauw, and Godlonton (2018) we show that the transfers (both cash and inputs) led to large increases in crop production over two years, driven by increased expenditures on inputs. Though intensive extensive was not effective on its own after year one, we find that it was complementary to the transfers: those who received both were better off than those who 
received the transfer only. There is also evidence that after two years receipt of extension services had an independent impact on production.

We find suggestive evidence that the cash transfers in Senegal reduced the total number of decision makers in the household and the likelihood that a female was a decision maker following the season in which the transfers were administered. One year later such effects are no longer present. In Malawi, we find the opposite. Both cash and input transfers have a short-run positive impact on decision-making measures. There is suggestive evidence that input transfers have a greater impact on decision making than cash transfers. Impacts related to the number of decision makers in the household persist after two years, but those related to female decision making do not. An analysis of the joint impacts of the transfer and the extension treatments finds that the positive impacts of the transfers are driven by those households that receive both transfers and intensive extension in the first year.

This work is linked to some existing research that studies the impact of cash transfers on women's decision making and empowerment. Most papers focus on transfers given directly to women. Ambler (2016) finds that pension receipt by women in South Africa leads to large increases in the recipient's decision-making power, which correlates with her increased income share. De la Briére and Quisumbing (2000) find that Progresa tranfers in Mexico have a small, but negative impact on the husband being the sole household decision maker. Transfers given to women (instead of men) led to an increase in a female empowerment index in a study in Kenya (Haushofer and Shapiro 2016). Studies of a transfer program in Macedonia showed that transfers given to women (compared to cases where they were given to men) resulted in increased bargaining power as measured through a lab-based exercise, but not when examining survey-based measures of decision making (Almas, Armand, Attanasio, and Carneiro 2018). Numerous other 
studies do not examine transfers specifically but demonstrate the link between income and bargaining power and decision making (Lundberg, Pollack, and Wales 1996; Duflo 2003; Qian 2008; Anderson and Eswaran 2009).

The literature also goes beyond income to study the impact of other elements of bargaining power and financial control on decision making. Banerjee at al. (2015) find no impact of access to microcredit on women's decision making and empowerment. Ashraf, Karlan, and Yin (2010) find that access to commitment savings accounts led to gains in decision-making power for women with below-median baseline levels of that same variable. Finally, Majlesi (2014) shows that increased access to employment results in improved decision-making power for women in Mexico.

This paper contributes to this literature by examining the short- and medium-run impacts of a program that provides a one-time infusion of support, instead of transfers given continuously over a longer time period. To our knowledge, the only study that speaks to the efficacy of onetime versus continued transfers is Haushofer and Shapiro (2016), who did not find any difference between the two modalities. However, even the monthly transfers in that study were time-limited. While most research is focused on examining how transfers and income specifically attributable to women affects decision making, we examine programs that are not necessarily targeted directly to women, but which do have elements that are intended to draw household members, both men and women, into household decision making. Importantly, we also look past transfers to programs that also provide services in conjunction with the transfers. Finally, the study of partner programs in Senegal and Malawi allow us to understand how program context may affect the impacts of such a program. 
The paper proceeds as follows. Section 2 describes the experimental design, Section 3 explains the data, Section 4 the empirical strategy, and Section 5 details the results. Section 6 concludes.

\section{Experimental Design}

This paper considers the impacts of two related, but distinct, projects on measures of household decision making. In this section we describe the relevant elements of the design of each project. Further details can be found in Ambler, de Brauw, and Godlonton (forthcoming and 2018).

\section{A. Senegal}

The Senegal project was conducted in partnership with the Fédération des Organisations Non-Gouvernementales du Sénégal (FONGS), an umbrella group of autonomous farmers associations with near national coverage. We work with eight associations located in central and western Senegal during the 2014/2015 and 2015/2016 agricultural seasons. The total sample is 600 households, comprising 15 villages in each association and 5 households in each village.

Project implementation largely occurred through an animateur, a farmer from the local area (but not the same village), who was trained to provide the support services the project offered. Animateurs worked in one or two villages, so randomization occurred at the animateur level to ensure that no animateurs would have to administer more than one treatment. Animateurs were mostly male and fewer than half had a high school education. Randomization was stratified by association and number of villages per animateur, in 11 distinct stratification cells. ${ }^{3} \mathrm{~A}$ timeline of project activities can be found in Figure 1. Animateurs and their associated households were allocated into one of three groups:

\section{Control group: Advisory visits only}

\footnotetext{
${ }^{3}$ Only 11 animateurs, in three associations, were assigned to more than one village, meaning the randomization was close to village level.
} 
The comparison group for our analysis received the light-touch treatment of monthly advisory visits from their animateur. These advisory visits were intended to assist farmers with issues related to their farms, principally regarding management issues. Animateurs were not trained to provide technical advice, but sometimes connected farmers with other services. Households in the control group also participated in the FONGS Basic Agricultural Assessment (BAA) which is a survey-like instrument, administered by the animateur, that collected information related to agricultural production and household expenses. The BAA was administered three times, prior to implementation in 2014, and after harvest in both year 1 (2015) and year 2 (2016). FONGS uses the BAA served to measure progress, and also as tool for households to learn about their financial situation.

\section{FMP group: Advisory visits and farm management plan}

This group received the same services as those in the control group, and additionally completed a farm management plan with their animateur in both years prior to the beginning of the agricultural season. The goal of this plan was to improve production-related measures by helping farmers to more effectively allocate their resources across their farms and over the season. Guided by the animateur, farmers created a schedule of activities and thought through likely challenges and preemptively devised solutions.

\section{FMP + Cash group: Advisory visits, farm management plan, and cash transfer}

Farmers in this group received all the same services as those farmers in the FMP group, and additionally received a one-time cash transfer of approximately USD200 timed near planting of the first year of implementation. The size of the transfer was large relative to total household resources, equal to approximately 15 percent of the baseline value of crop production. Note that while support services continued for two years, the transfer was only given once, at the beginning 
of year one. The transfer was unconditional, but heavily framed for agricultural investment and implementation of the farm management plan. ${ }^{4}$ The transfers were distributed to household heads by GRET, an NGO assisting FONGS in project implementation. The animateurs were not involved in transfer distribution.

The focus of our analysis will be on the FMP + Cash treatment because we expect that the infusion of resources into the household could have a direct effect on household decision making. In this context, because the transfers were given directly to the household head (almost always male), we do not necessarily expect that the program would increase the decision-making power of women or other males in the household. At the same time, the project as a whole was designed to include the entire household, and to promote joint planning and decision making. As such, the management plan alone may impact decision-making measures, and the infusion of cash in conjunction with these services may also increase the participation of others in decision making.

\section{B. Malawi}

The project in Malawi was conducted in partnership with the National Smallholder Farmers Association of Malawi (NASFAM), a nationwide organization that provides farmers with both social and commercial services. NASFAM operates through self-organized farmer clubs. Standard services received by clubs include input starter packages, repayable to NASFAM seed banks, and some group-based extension services, provided by a lead farmer. NASFAM commercial services also provide a guaranteed market and price for a specific cash crop of focus. In this study we worked with 120 farmer clubs in the Dowa and Ntchisi districts of central Malawi. The clubs averaged ten members each, leaving us with a target sample size of approximately 1,200

\footnotetext{
${ }^{4}$ Benhassine et al. (2015) find the framed cash transfers for education can be as effective as conditioned transfers in directing funds towards their intended use.
} 
smallholder farmers. Project implementation was conducted during the 2014/2015 and 2015/2016 agricultural seasons. Figure 2 details the project timeline and experimental design.

Because a large component of the project (to be detailed below) was conducted by extension agents, clubs were first assigned to extension agents. Treatment randomization was then done at the club level, and stratified by extension officer, an indicator for above the median share of females in the club, and an indicator for above the modal club size. The project involved two cross-cutting interventions: a transfer treatment and an intensive extension treatment. Here we detail both in turn.

\section{Transfer treatment: Control}

Farmers in the control group of the transfer treatment received only standard NASFAM services, and no additional resources. If the farmer was newly registered that meant they received a seed loan equal to about two-thirds of the value of the seed disbursement given in the other groups, but which was repayable with interest to NASFAM. Other farmers received no capital support.

\section{Transfer treatment: Cash}

Cash transfers were distributed during the first year of implementation only, in three tranches, equal to about $\$ 84$ in value. As in Senegal, the total value of the transfer was equal to about 15 percent of the baseline value of crop production. Farmers were given disbursements of \$36 (November 2014), \$22 (February 2015), and \$26 (April 2015). As in Senegal, the transfers were unconditional, but heavily framed for investment in specific agricultural inputs appropriate at the time of each transfer. Transfers in Malawi were allocated to the NASFAM club member, not the household head, who could be either male or female. 64 percent of club members in our sample are female. 


\section{Transfer treatment: Inputs}

The third group of farmers received a combination of cash and inputs, timed at the same time as the cash transfers. The first disbursement was comprised of seed, inoculant (a nitrogen fixer), and hoes. The second was given in cash to pay for ganyu (day-labor, which was the relevant input for these farmers mid-season), and the third included improved storage sacks, strings, and cash for harvest-related activities. ${ }^{5}$ Again, transfers are distributed to the NASFAM member, not necessarily the household head.

As in the Senegal analysis, the bulk of our analysis will concern the transfer treatments, because the household decision-making measures under consideration are directly linked to household resources. The comparison of the cash and input transfers is particularly interesting in this case given that the input transfers are restricted to certain things, while the cash is more flexible. Of course, any increased output or income that results from the transfers may also affect decision making in the household, but that output may or may not be connected to a specific household member. However, we will also explore the joint impact of the transfer treatment with the extension treatment, described below. The extension treatment was also randomized at the club level, stratified in the same way, and was additionally stratified on the transfer treatment.

\section{Extension treatment: Standard services}

The control treatment for the extension intervention received only standard NASFAM extension services. This is primarily a lead farmer approach, where a NASFAM member is selected by other farmers to be a lead farmer. The lead farmer then receives trainings from

\footnotetext{
${ }^{5}$ Farmers in both the cash and inputs group were also required to participate in a modified version of the NASFAM seed bank that promoted transfer sustainability by requiring seed savings between the first and second season. For details see Ambler, de Brauw, and Godlonton (2018).
} 
NASFAM extension agents, and is encouraged to share that knowledge with other farmers in their area, primarily through group-based activities.

\section{Extension treatment: Intensive extension}

Farmers in this group receive the standard NASFAM services, and additionally receive individual extension support from trained, professional extension agents. Like in Senegal this support includes farm management planning, but it also includes individualized technical support. Farmers received at least three one-on-one visits from extension agents over the season. A detailed farm management plan was completed during the first visit, and subsequent visits focused on support to complete this plan as well as any additional technical issues farmers were experiencing. To support the project, NASFAM hired 15 additional extension agents. The transfer treatment was conducted only in the first year of implementation, but the extension treatment was implemented in both the first and second years. ${ }^{6}$

While the connection of the extension treatment to household decision making is not as direct as with the transfer treatment, the support and knowledge received by farmers could lead to changes. Women who receive training from extension agents may have more agency and knowledge with regards to production. Men in the intensive services group may also learn skills, both technical and management related, that result in changes in the way household decision making is organized. The interactions of the two treatments is of particular interest, given that we find the two are complementary in increasing crop production in the first year.

\section{Data}

\footnotetext{
${ }^{6}$ In the second year of the project, the extension treatment was re-randomized so that $1 / 4$ of farmers never received intensive services, $1 / 4$ received them in year one only, $1 / 4$ received them in year two only, and $1 / 4$ received them in both years. However, because this paper will focus on the transfer treatment and only study the interaction of the transfers with the extension treatment, we will address only the year one randomization here.
} 
The data used to evaluate the impact of the Senegal program on decision making outcomes comes from data collected at project baseline, midline, and endline. Due to project timing and the preferences of FONGS, no baseline data was collected by the research team, and the only baseline data available is that collected by FONGS during the BAA. This data is limited and does not contain any decision making outcomes, but can be used descriptively and to test for balance. See Ambler, de Brauw, and Godlonton (forthcoming) for a detailed description of balance tests demonstrating the success of the treatment randomization.

The midline and endline data are complete household surveys supervised by the research team. These instruments collected a large amount of data on agricultural outcomes and other household welfare measures. They contain a section on decision making asking for the identity of the household decision makers in a variety of household activity categories, and additionally contain questions about decision making over crop production on a crop-by-crop basis, and livestock decision making by animal. The livestock questions were asked at endline only, while all others were asked at both midline and endline.

Due to partner concerns about respondent fatigue, the midline survey was targeted to only 240 households out of 600 . These households were randomly chosen at the village level, stratified by treatment and association. Ambler, de Brauw, and Godlonton (forthcoming) show that the midline sample is not statistically different from the sample not selected for the midline. The endline survey was conducted with the full sample of 600 households. Attrition was minimal, 239 and 598 households were successfully interviewed at midline and endline respectively, with the missing households due to household-level refusals in all three cases. ${ }^{7}$

\footnotetext{
${ }^{7}$ Because FONGS wished to incorporate capacity building into the administration of the surveys, the enumerator teams were comprised of FONGS animateurs, chosen for their technical capability, one per association at midline, and two per association at endline. In only 25 cases at midline, and none at endline, were households interviewed by
} 
The Malawi data comes from three researcher-implemented surveys: prior to program implementation (baseline), following harvest of year 1 (follow-up 1), and following harvest of year 2 (follow-up 2). The Malawi project also included several additional rounds of data collection midseason and following the second year of implementation, but these do not include decision making outcomes, so are not relevant for this analysis. ${ }^{8}$ The full sample is all farmers who were members of the selected farmer groups at baseline, and this full sample was targeted in each survey round, regardless of whether they remained in the farmer club. ${ }^{9}$ The baseline sample was 1,187 households. 1,114 households were interviewed at follow-up 1, and 1,017 households were interviewed at follow-up 2. These numbers do not provide a full picture of attrition because the follow-up rounds do include some famers who were not found for interview at baseline, but who were club members at that time, and who therefore received services.

As in Senegal, the Malawi surveys contain information on a large number of outcomes related to agricultural production and other aspects of household welfare. Baseline data confirms that the treatment groups were well-balanced (see Ambler, de Brauw, and Godlonton 2018). The decision-making measures are similar to those in the Senegal surveys, covering five categories of household activities and crop- and livestock-level decision making. They additionally contain questions regarding decision making about the use of different agricultural inputs and the implementation of different agricultural technologies. Some, but not all, of these measures are available at baseline in addition to the two follow-up surveys.

\footnotetext{
their assigned animateur. Animateur enumerators were closely supervised by external supervisors at a ratio of one supervisor for every two enumerators. All trainings and management were conducted by the research team.

${ }^{8}$ These additional rounds of data preclude us from using the terms "midline" and "endline" to describe the Malawi data.

${ }^{9}$ Follow-up 2 also included new farmers added to clubs between year 1 and year 2, but we do not consider these new farmers in our analysis as they did not receive the transfer treatments or extension treatments in year 1 . Sample numbers shown here exclude new farmers.
} 
Table 1 provides baseline summary statistics on a number of baseline outcomes, for both Malawi and Senegal. The two samples have similar rates of female headed households (12 and 14 percent in Senegal and Malawi respectively), however household composition is quite different. Household heads in Senegal are much older (53) than in Malawi (44), and polygamy is more common (42 percent in Senegal compared to 10 percent in Malawi). The Senegalese households are much larger, with an average of 16.5 members, compared to 5.5 in Malawi. This difference is due in part to an expansive household definition used in the Senegal project that incorporates extended families that live on family compounds, but household size is also simply much larger in the Senegalese context. These differences in family structure will be important to consider when examining household decision making across countries. Household heads are also much more educated in Malawi, where 86 percent of heads have some education, compared to only 33 percent in Senegal.

There are also differences on agricultural measures; the households in Malawi grow more crops on average than the Senegalese households, but the value of total output is almost three times higher in Senegal. Households in Senegal are also more productive: output per hectare is USD213 in Senegal and USD128 in Malawi. Livestock is additionally more important in Senegal, where total holdings are worth USD2,270 on average, compared to only USD196 in Malawi.

In Table 2 we present mean values for the decision-making variables that we use as the outcome variables in our analysis. Midline and endline means for Senegal are presented in columns 1 and 2, and baseline, follow-up 1, and follow-up 2 means for Malawi are presented in columns 3 through 5. If a certain figure is missing, it was not included in that survey round in that country. Appendix 1 describes the construction of these variables in detail. The first set of variables considers the number of unique decision makers in each household across of variety of categories. 
These variables are designed to test the overall inclusion of household members in decision making, regardless of gender. For decisions about household activities respondents could list up to five decision makers in Senegal and three in Malawi,${ }^{10}$ and we list the average number of decision makers reported for each category. We also report the number of unique decision makers across all five activities. We then report the number of unique decision makers reported across all crops, all livestock, all agricultural inputs, and all agricultural technologies. In these categories, respondents were limited to reporting two decision makers per crop, animal type, input, or technology in both countries.

We also present a set of variables examining female decision making specifically as a primary goal of the analysis is to understand whether the transfers increase female participation in decision making. These variables report whether a female decision maker is reported at all among the decision makers for each activity, across activities, across crops, across animal types, across agricultural inputs, and across agricultural technologies. For the aggregate categories, we also report the proportion of activities, crops, livestock, inputs, or technologies, for which a female decision maker is listed. For the activity categories, the survey also asked respondents to indicate whether each individual selected had most or equal say in the decision. We therefore also construct a similar set of variables based on whether a female had most or equal say instead of whether or not she simply participated. ${ }^{11}$

The number of decision maker variables are generally comparable across Senegal and Malawi, with a tendency to be slightly higher in Malawi. These averages are mostly between 1.3 and 1.8, with only few exceptions. However, given the much larger household size in Senegal,

\footnotetext{
${ }^{10}$ At baseline this was limited to two in Malawi.

${ }^{11}$ If only one decision maker is listed, that person is by default assumed to have most say in the decision. Because of low variation in this variable in the Senegal data (very few women in Senegal are reported to have most or equal say in decisions), we do not use this information in our analysis for Senegal.
} 
these numbers represent a much lower proportion of the household involved in decision making Senegal compared to Malawi. When considering female decision making, we observe large differences between the two contexts. In Senegal, the percentage of households with a female decision maker for any given activity is under 20 in almost all cases. The averages are higher when considering crops and livestock (about 50 percent at endline), but the proportion of crops and animals with a female decision maker is still low. In Malawi the percentages of households with a female decision maker, in any of the considered categories, is much higher, generally around 70 or 80 percent. The proportion of activities, crops, animals, etc. is also in this range, further differentiating the pattern from the numbers in the Senegal sample. When considering cases where a female has most or equal say in the decision, the numbers are lower, closer to 40 or 50 percent. In general Table 2 shows that decision making in Senegal is more concentrated among a smaller number of household members, and, additionally, women are much less likely to be involved in any type of decisions.

\section{Empirical Strategy}

In both countries we analyze the impact of the treatments on decision making outcomes, exploiting the randomized assignment to identify the causal impact of the programs.

\section{A. Senegal}

Using the Senegal data, we estimate an ordinary least squares regression of the following form, run separately at midline and endline:

$Y_{i a t}=\alpha+\beta_{F M P} T_{F M P a}+\beta_{F M P+C a s h} T_{F M P+C a s h a}+\delta_{s c}+u_{i a}$,

where $i$ indexes households, $a$ the animateurs, $t$ the time period (midline or endline), and $s c$ the stratification cell. $Y_{i a t}$ is the outcome variable. $T_{F M P ~} a$ and $T_{F M P+C a s h} a$ are indicator variables for the FMP group and the FMP + Cash group and the associated $\beta$ coefficients represent the average 
difference in the outcome variable between that treatment group and the control group. $\delta_{s c}$ are the stratification cell fixed effects. Standard errors are clustered by animateur. Each regression table considering the Senegal analysis will contain two panels, with the midline results presented in the top panel, and the endline results presented in the bottom panel. Each panel will also present the p-value on a test for equality of $\beta_{F M P}$ and $\beta_{F M P+C a s h}$. In both countries, the regressions for number of unique decision makers across categories also control for the number of categories the household engages in, i.e. the number of crops grown or livestock types owned.

\section{B. Malawi}

In Malawi, we similarly use ordinary least squares to estimate the impact of the program on decision making outcomes. We first examine the impact of the transfer treatment using the following specification, run separately at follow-up 1 and follow-up 2:

$Y_{h j}=\alpha+\beta_{\text {Cash }} T_{\text {Cash } j}+\beta_{\text {Inputs }} T_{\text {Inputs } j}+\tau Y_{h 0}+\delta_{s}+\varepsilon_{h j}$,

where $Y_{h j}$ is a measure of decision making in household $h$ in farmer group $j . T_{\text {Cash } j}$ is an indicator variable that takes the value of 1 if the respondent's club was assigned to the cash transfer, and $T_{\text {Inputs } j}$ indicates whether the farmer was assigned to receive the input transfer. $\beta_{\text {Cash }}$ and $\beta_{\text {Inputs }}$ are the mean difference between the outcome variable in each treatment group and the control group. When possible, we present the ANCOVA specification and control for the baseline value of the outcome variable, $Y_{h 0} \cdot{ }^{12} \delta_{s}$ represents stratification cell fixed effects. Standard errors are clustered by farmer club. All tables will also present the $\mathrm{p}$-value for equality of $\beta_{\text {Cash }}$ and $\beta_{\text {Inputs }}$ to study whether the two transfer treatments had differential impacts on decision making.

\footnotetext{
12 The ANCOVA specification is only possible when the outcome was also collected at baseline. In some cases the decision making question was added between baseline and follow-up 1 and in some cases the format of the question was changed. For consistency, we include the baseline value only when is exactly the same as the follow-up outcomes. All baseline values reported in Table 2 meet this requirement.
} 
To further study the impact of the program on decision making, we also consider the interaction of the transfer treatments with the extension treatment from year 1 in the following form:

$$
\begin{gathered}
Y_{h j}=\alpha+\beta_{\text {Trans }} T_{\text {Trans } j}+\beta_{\text {Ext }} T_{\text {Ext } j}+\beta_{\text {Trans }+E x t} T_{\text {Trans }+ \text { Ext } j} \\
+\tau Y_{h 0}+\gamma T_{E x t Y r 2}+\delta_{s}+\varepsilon_{h j},
\end{gathered}
$$

where all repeated variables are as before. In this specification we collapse the cash and input treatments into one indicator to improve power. $T_{\text {Trans } j}$ is an indicator for households that received the transfer only, $T_{E x t} j$ is an indicator for households that received intensive extension

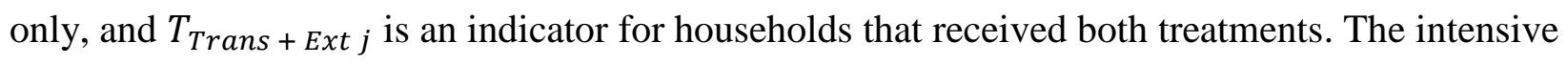
extension treatment indicator used here refers only to the extension treatment that was administered in year 1 . Thus, the follow-up 2 regressions only additionally control for the intensive extension treatment assignment for year $2\left(T_{E x t} Y r_{2}\right)$, though it is not a parameter of interest in our current analysis.

\section{Results}

\section{A. Senegal}

We begin by examining the impact of the treatments in the Senegal program on decision making in participant households. Table 3 shows the results for variables related to the number of decision makers. The number of decision makers for each activity are presented in columns 1 through 5 , the number of unique decision makers across all activities in column 6 , number of unique decision makers across all crops in column 7 , and number of unique decision makers across all livestock in column 8. Midline results are in the top panel and endline results are in the bottom panel. P-values are listed below coefficients in parentheses. 
At midline, there is no evidence that receiving the management plan only had any impact on any of the variables considered; none of the coefficients are statistically significant for the FMP group and they are also generally small in size. The coefficients in the FMP + Cash group however are negative across all specifications and generally larger. Though the analysis in the midline sample is somewhat underpowered, two of these indicators are statistically significant: for number of decision makers for large, unusual purchases, and number of unique decision makers across all crops. These two are large effects, representing a 13 percent and 25 percent decline in the number of decision makers in these two categories. While these are the only two statistically significant results, the pattern of all coefficients is very consistent, suggesting that in Senegal the transfer treatment had the impact of concentrating decision-making power with fewer household members and not expanding it. The management plan alone did not expand decision making either, despite the stated goal of increasing overall household involvement in planning and decision making. It should be noted that in general we cannot reject that the coefficients for the FMP and FMP + Cash group are the same, with the exception of the crop variable. Overall, the midline results are suggestive, but not conclusive.

At endline there is no statistically significant impact of either treatment on any outcome related to the number of decision makers. While the coefficients do tend to be negative, they are also in general much smaller than the estimates at midline for the FMP + Cash group. While there is suggestive evidence that the cash transfer acted to concentrate decision making power in the period immediately following its receipt, that effect seems to have dissipated by endline. This indicates that it is the receipt of the cash itself that had an impact, and not any continued benefits the household is experiencing at endline (in this case, increased livestock holdings). 
Table 4 presents results for the impacts of the treatments on female decision making in Senegal. Columns 1 through 5 show results for whether there was a female decision maker or not for each activity category and columns 6 and 7 show whether there was a female decision maker for any activity and the proportion of activities with a female decision maker. The same variables for crops are shown in columns 8 and 9, and livestock in columns 10 and 11 . In line with the results in Table 3, the midline results shown for the FMP + Cash group are consistently negative and large in magnitude, particularly when compared to the control mean. However, these results are statistically significant only for whether there is a female decision maker for any crop and the proportion of crops with a female decision maker. The estimated coefficients are large in magnitude compared to the control group: a 51 percent reduction in the probability there is a female decision maker and a 49 percent reduction in the proportion of crops grown with a female decision maker. Both of these estimates are also statistically different from the same estimates for households in the FMP group. Though we are underpowered on most of the measures presented here, the results from Tables 3 and 4 do show that the cash transfer resulted in a reduction in the number of decision makers for crops that was driven by a reduction in female decision makers specifically. This is interesting because the cash transfers were given to the household head (almost always male) and heavily framed for agricultural investment.

Again, there are no statistically significant estimates for the FMP group. The measured coefficients do exhibit a negative pattern, but are generally (though not always) small in magnitude. Estimates for both treatments at endline are all also small and not statistically significant, suggesting that the documented patterns from midline did not last. In general, the aspect of the program that promoted joint, family decision making seems to have had less impact than the transfers. 


\section{B. Malawi}

We now turn to the impact of the Malawi program on similar decision-making measures. We begin by estimating the impact of the transfer treatment (equation 2), on the number of decision makers across a variety of categories. This table is constructed in the same way as Table 3 for the Senegal results, with the addition of number of decision makers across agricultural impacts (column 9) and across agricultural practices (column 10).

The follow-up 1 results in Malawi are strikingly different from those in Senegal. All estimated coefficients for both cash and inputs are positive, suggesting that the transfers increased the number of decision makers in households in Malawi. The results are statistically significant for the cash group for decisions about day-to-day household needs and the number of unique decision makers across all activities. These coefficients represent a 7 percent and a 4 percent increase in the number of decision makers relative to the control group mean. The results for the input transfer group are generally somewhat larger and very robust; the estimates are statistically significant for all but one specification. The magnitude of these increases ranges from three to 11 percent of the control mean, with most in the five to seven percent range. The relative size of these impacts is smaller than in Senegal. However, because the household size in Malawi is much smaller but the control means are similar, there is less room for movement in the Malawi case. In three cases (where/if children go to school, who is allowed to live in the household, decision makers across livestock) we can reject that the impacts of the cash and inputs are the same. Overall, the pattern of results is strongly suggestive that the inputs had a larger impact than the cash.

The results presented for follow-up 2 in the bottom panel of Table 5 are not as clear are those for follow-up 1. Though most coefficients for both groups continue to be positive, fewer are statistically significant. For the cash group, at follow-up 2, we estimate a reduction in the number 
of decision makers for day-to-day household needs and large, unusual purchases. There is also a statistically significant increase in the number of decision makers for livestock. For the inputs group, four of the ten estimates are statistically significant: decisions about where/if children go to school, household investment in agriculture and livestock, decision makers across all crops, and decision makers across all agricultural practices. In two of these cases (school and agricultural practices) the inputs coefficient is statistically larger than the cash coefficient. These coefficients are of a similar magnitude as the results at follow-up 1. Overall, the follow-up 2 results suggest that there is some persistence in the impact of the transfers on number of household decision makers, particularly for the input treatment, but this is not as robust as at follow-up 1.

We now examine the impact of the transfer treatments on female decision making in Table 6. The table is comparable to Table 4 for Senegal, with the addition of agricultural inputs and practices. The follow-up 1 results in the top panel closely mirror the results for number of decision makers in Table 5. Coefficients are all positive and statistically significant in seven cases for the cash treatment and in ten cases for the input treatment. The pattern of significant results is not concentrated among any single family of outcomes, and they range in size from 6 to 20 percent of the control mean. Recall that these increases are off the already high levels of female decision making noted in Table 2. Again, there is a suggestive pattern that the inputs transfer had a larger impact than the cash transfer, but we can only reject that the coefficients are the same in three cases.

As in Table 5, the results for follow-up 2 are less conclusive. The coefficients for the cash group are largely very small and some are negative. Although the coefficients for the inputs group are slightly larger, only one, across all 15 categories, is statistically significant. If there is any persistence in the number of decision makers in the household from year 1 to year 2 , that 
persistence is not driven by an increase in female decision making, at least that we can detect in our sample.

Given the high rates of female participation in decision making in the Malawi sample at baseline and in the control group, in Table 7 we analyze the impacts of the transfer treatment on whether a woman has most or equal say in the decision, instead of simply whether or not she participated. As shown in Table 2, the means for this variable are much lower, and increases are more indicative of a meaningful female role in decision making. We have this variable only for decisions about activities, but Table 7 is otherwise constructed in a parallel manner to columns 1 through 7 of Table 6 .

At follow-up 1 we find consistent evidence that transfer treatments increased the probability that a woman had most or equal say in decisions. Five of seven coefficients for the cash treatment, and three of seven for the inputs treatment, are statistically significant. The coefficients are large in magnitude, ranging from 12 to 29 percent of the control mean. Interestingly, the absolute percentage point increases are quite comparable to those in Table 6, suggesting that most of the changes documented there are due to women gaining most or equal say. However, one difference is that in Table 7 coefficient size between the cash and input groups is quite similar and there are no significant differences. The follow-up 2 coefficients are quite small and none are statistically significant, suggesting that the increases in these variables are not sustained into year 2 .

The final step in our analysis is to examine the interaction of the transfer and extension treatments implemented in the Malawi project. This analysis is of interest because though the transfers are more directly linked to the theories of household economics that describe how bargaining power is determined, the increased information the extension services provide to female 
farmers can directly serve to increase their role in household decision making, particularly regarding agricultural activities. Additionally, the planning exercises included in the intensive extension services may serve, as was hypothesized in the Senegal program, to increase joint decision making at a household level.

Table 8 presents the results of estimating the combined treatment effect as described in equation 3. To increase power, and because we cannot convincingly show that cash and inputs have differential impacts, we combine the cash and input treatments in this analysis and show the impact of receiving the transfer alone, intensive extension only, or both. We show this analysis for a subset of outcomes: number of unique decision makers across all activities, crops, livestock types, agricultural inputs, and agricultural practices in columns 1 through 5 , and the proportion of these same categories with a female decision maker in columns 6 through 10 .

Though overall we have less power in these interacted regressions, the results for the number of decision maker variables at follow-up 1 suggest that the increases in numbers of decision makers were driven by people who received both the transfer and the intensive extension (statistically significant for livestock, agricultural inputs, and agricultural practices). The coefficients for those who received only the transfer do not show a consistent pattern, and the estimates for those who received extension only are negative across all categories. The coefficients for those receiving both treatments are statistically different from those for households that received the transfer only in seven of ten cases, and from those that received extension only in all cases. Interestingly, this is consistent with the results presented in Ambler, de Brauw, and Godlonton (2018) which show that in the first year, intensive extension alone had a negative impact on crop production, while the combination of transfers and extension was most effective. 
Similar to the suggestive evidence in Table 5 that the transfers had some sustained impact on the number of decision makers at follow-up 2, columns 1 through 5 of the bottom panel of Table 8 also suggest that receiving both transfers and intensive extension have persistent impacts on the number of decision makers in year 2. At both follow-up 1 and follow-up 2 the coefficients for receiving both treatments are positive and large in magnitude for the four agricultural categories, while close to zero for the activities measure in column 1 . This is consistent with the hypothesis that the intensive extension is drawing more people into agricultural decision making. While the coefficients on both the transfer only and extension only treatments are mostly positive at follow-up 2, there is no consistent, statistically significant pattern.

Examining the proportion of female decision makers in each category at follow-up 1 shows a similar pattern. The documented increases from Table 6 appear to be driven by those that received both the transfer and the intensive extension services, and these estimates are statistically significant across all categories. There is no strong pattern for those who received the transfer only, and a negative trend for those receiving only extension services in year 1 . However, as with the analysis of the transfers only, none of these effects carry through to follow-up 2.

In sum, the results from Malawi show that the transfers had a large impact on the decision maker measures that we study after year 1 . Both types of transfers were effective, but the evidence generally points to the input transfers having a greater impact than the cash transfers. This is, however, not true when considering whether women had most or equal say in a decision instead of whether or not they simply participated. However, we only have this measure for household activities, and not for the specific agricultural measures. The positive impact of the transfers is driven by those households that received both the transfer and the intensive extension services in the first year. Persistence of impacts into year 2 (when transfers were not administered) are found 
only when considering the total number of decision makers in the household, not whether a female participated in decision making.

\section{Discussion and Conclusion}

This paper studies the impacts on household decision making of two related programs that provide transfers and agricultural support services to smallholder farmers, with strikingly different results. In Senegal, there is evidence that the cash transfer acted to reduce the number of household members involved in decision making in the short-run, particularly for decisions related to crop production. There is also suggestive evidence that female decision making was negatively impacted in this time period. These impacts appear to have largely dissipated when measured two years after receiving the transfer. While there is no evidence that receiving a management plan without the transfer impacted decision making, the experimental design does not allow us to disentangle any complementary effects. Conversely, the Malawi project positively impacted decision making in the short-run, with some evidence of persistence into year 2 when considering total household involvement, but not when examining female participation. The cross-cutting experimental design in Malawi does suggest that the transfers and support services were complementary in their impacts on household decision making. ${ }^{13}$

What explains these opposite results in the two countries? While we can only speculate, the two largest differences between the samples are household structure and levels of overall household and female involvement in decision making. The Senegalese households are much larger, and much more likely to be polygamous. They also have much lower levels of household involvement in decision making (as a percentage of total household size), and are much less likely to report that women are involved in decision making. Household heads are also less educated than

\footnotetext{
${ }^{13}$ It should be noted that because the Malawi study is better powered than the Senegal study, we are able to detect smaller impacts in Malawi than we are in Senegal.
} 
in the Malawi sample. These differences suggest that this type of program is more likely to impact household decision-making dynamics and women's empowerment in situations where decision making is already more egalitarian. The results from Malawi also indicate that the combination of services and transfers may be important if household decision making is a primary goal. However, the fade out of most impacts by the second year also indicates that one-time infusions of support are not sufficient to permanently empower women or impact agricultural decision making, even when the transfers have been shown to have persistent impacts on agricultural production. 


\section{$\underline{\text { References }}$}

Almas, Ingvild, Alex Armand, Orazio Attanasio, and Pedro Carneiro. 2018. "Measuring and Changing Control: Women's Empowerment and Targeted Transfers." The Economic Journal 128(July): F609-F639.

Ambler, Kate. 2016. "Bargaining with Grandma: The Impact of the South African Pension on Household Decision Making." The Journal of Human Resources 51(4): 900-932.

Ambler, Kate, Alan de Brauw, Susan Godlonton. 2018. “Agricultural Support Services: Direct Effects, Complementarities, and Time Dynamics.” IFPRI Discussion Paper 01725.

Ambler, Kate, Alan de Brauw, Susan Godlonton. Forthcoming. "Cash Transfers and Management Advice for Agriculture: Evidence from Senegal." World Bank Economic Review. Previous version IFPRI Discussion Paper 01659.

Anderson, Siwan and Mukesh Eswaran. 2009. "What Determines Female Autonomy? Evidence from Bangladesh.” Journal of Development Economics 90(2): 179-91.

Ashraf, Nava, Dean Karlan and Wesley Yin. 2009. "Female Empowerment: Impact of a Commitment Savings Product in the Philippines." World Development 38(3): 333-44.

Banerjee, Abhijit, Esther Duflo, Rachel Glennerster and Cynthia Kinnan. 2015. "The Miracle of Microfinance? Evidence from a Randomized Evaluation." American Economic Journal: Applied Economics 7(1): 22-53.

Benhassine, Najy, Florencia Devoto, Esther Duflo, Pascaline Dupas, and Victor Pouliquen. "Turning a Shove into a Nudge? A "Labeled Cash Transfer" for Education." American Economic Journal: Economic Policy. Forthcoming.

Browning, Martin, Pierre-André Chiappori, and Yoram Weiss. 2014. Economics of the Family. New York, NY: Cambridge University Press.

Chiappori, Pierre-André. 1988. "Rational Household Labor Supply.” Econometrica 56(1): 63-89.

Chiappori, Pierre-André. 1992. "Collective Labor Supply and Welfare.” Journal of Political Economy 100(3): 437-67.

De la Brière, Bènèdicte and Agnes Quisumbing. 2000. "Final Report: The Impact of Progresa on Women's Status and Intrahousehold Relations.” IFPRI report.

Doss, Cheryl. 2013. "Intrahousehold Bargaining and Resource Allocation in Developing Countries." World Bank Research Observer 28(1): 52-78.

Duflo, Esther. 2003. "Grandmothers and Granddaughters: Old-Age Pensions and Intrahousehold Allocation in South Africa." The World Bank Economic Review 17(1): 1-25. 
Duflo, Esther. 2012. "Women's Empowerment and Economic Development." Journal of Economic Literature 50(4): 1051-79.

Haushofer, Johannes and Jeremy Shapiro. 2016. "The Short-term Impact of Unconditional Cash Transfers to the Poor: Experimental Evidence from Kenya." The Quarterly Journal of Economics 2016: 1973-2042.

Lundberg, Shelly and Robert A. Pollack. 1994. "Non-cooperative Bargaining Models of Marriage." American Economic Review Papers and Proceedings 84(2): 132-37.

Lundberg, Shelly and Robert A. Pollack. 1996. "Bargaining and Distribution in Marriage." The Journal of Economic Perspectives 10(4): 139-158.

Lundberg, Shelly, Robert A. Pollack and Terence J. Wales. 1996. "Do Husbands and Wives Pool Their Resources? Evidence from the United Kingdom Child Benefit." Journal of Human Resources 32(3): 463-80.

Majlesi, Kaveh. 2014. "Labor Market Opportunities and Women's Decision Making Power within Households." Lund University Department of Economics Working Paper 2014:4.

Manser, Marilyn and Murray Brown. 1980. "Marriage and Household Decision-Making: A Bargaining Analysis." International Economic Review 21(1): 31-44.

McElroy, Marjorie B and Mary Jean Horney. 1981. "Nash Bargained Household Decisions." International Economic Review 22(2): 333-49.

Qian, Nancy. 2008. "Missing Women and the Price of Tea in China: The Effect of Sex-specific Earnings on Sex Imbalance." The Quarterly Journal of Economics 123(3): 1251-85. 
Figure 1: Project timeline: Senegal

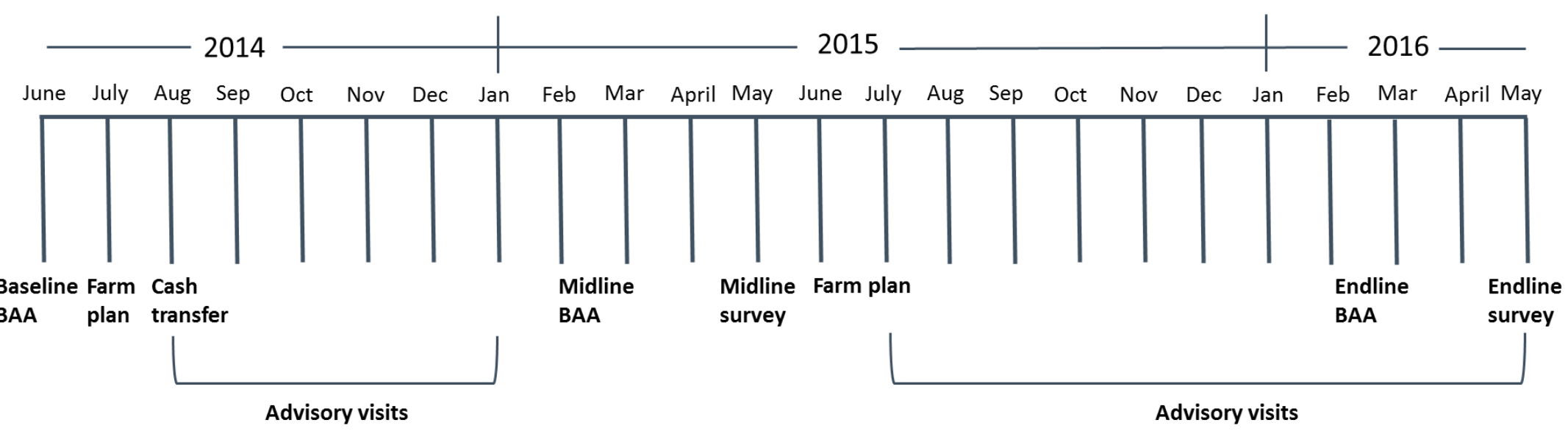


Figure 2: Project timeline: Malawi

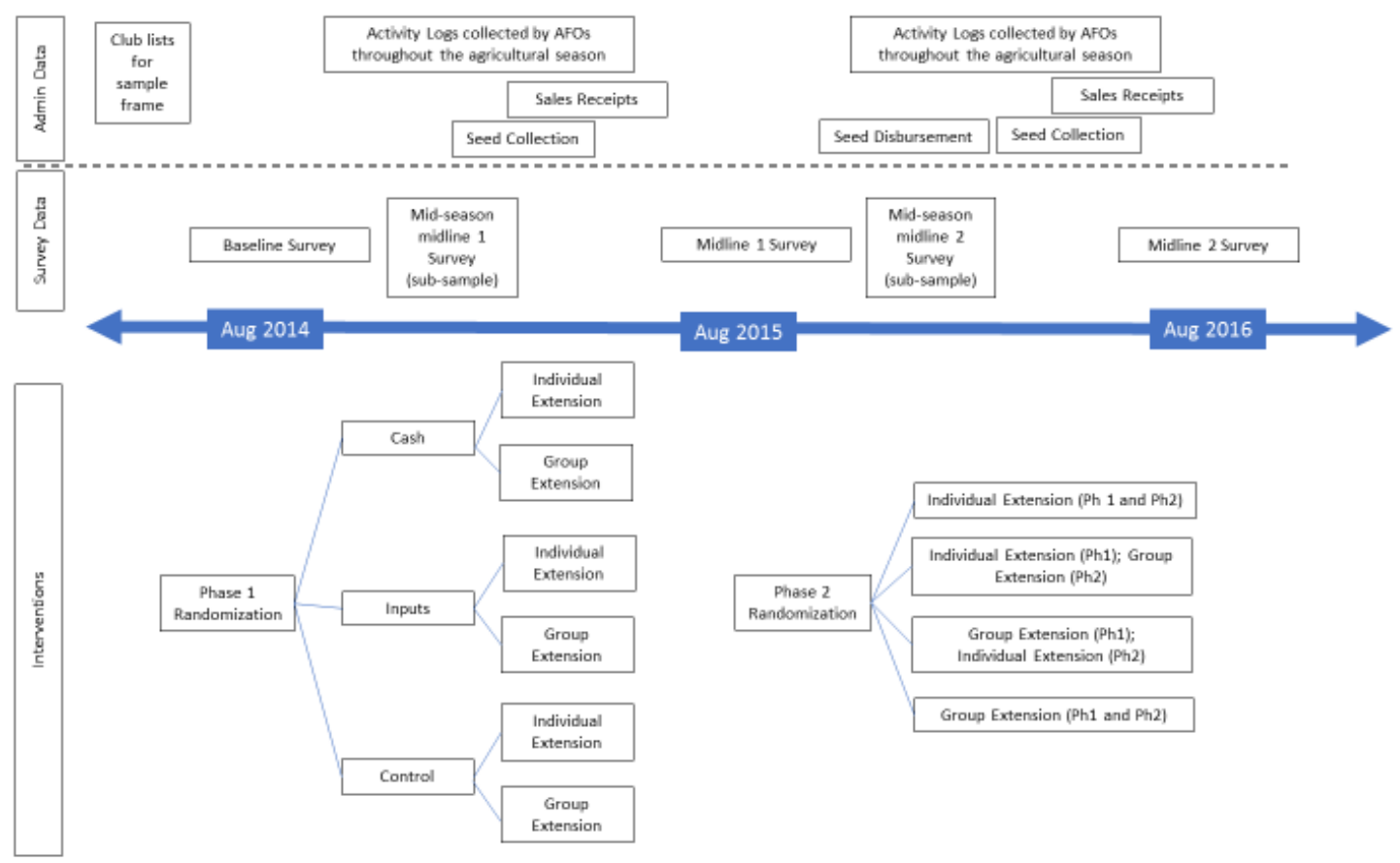


Table 1: Baseline summary statistics

\begin{tabular}{|c|c|c|c|c|}
\hline & \multicolumn{2}{|c|}{ Senegal } & \multicolumn{2}{|c|}{ Malawi } \\
\hline & $\begin{array}{c}\text { Mean } \\
\text { (1) }\end{array}$ & $\begin{array}{c}\text { Number of } \\
\text { observations } \\
(2)\end{array}$ & $\begin{array}{l}\text { Mean } \\
\text { (3) }\end{array}$ & $\begin{array}{c}\text { Number of } \\
\text { observations } \\
(4)\end{array}$ \\
\hline Household head is female & 0.12 & 600 & 0.14 & 1,185 \\
\hline Age of household head & 53.09 & 598 & 44.34 & 1,183 \\
\hline Household head is polygamous & 0.42 & 600 & 0.10 & 1,185 \\
\hline Household head has at least some education & 0.33 & 600 & 0.86 & 1,185 \\
\hline Household size & 16.54 & 600 & 5.55 & 1,187 \\
\hline Number of crops grown & 3.21 & 600 & 4.54 & 1,187 \\
\hline Gross value of agricultural output (USD) & $1,461.48$ & 600 & 600.12 & 1,187 \\
\hline Gross value of agricultural output per hectare (USD) & 212.94 & 599 & 128.28 & 1,182 \\
\hline Tropical livestock units & 3.57 & 600 & 0.76 & 1,186 \\
\hline Total value of livestock owned (USD) & $2,270.71$ & 600 & 196.43 & 1,187 \\
\hline
\end{tabular}

Notes: Author's calculations from Senegal baseline BAA and Malawi baseline survey. 
Table 2: Decision making variables

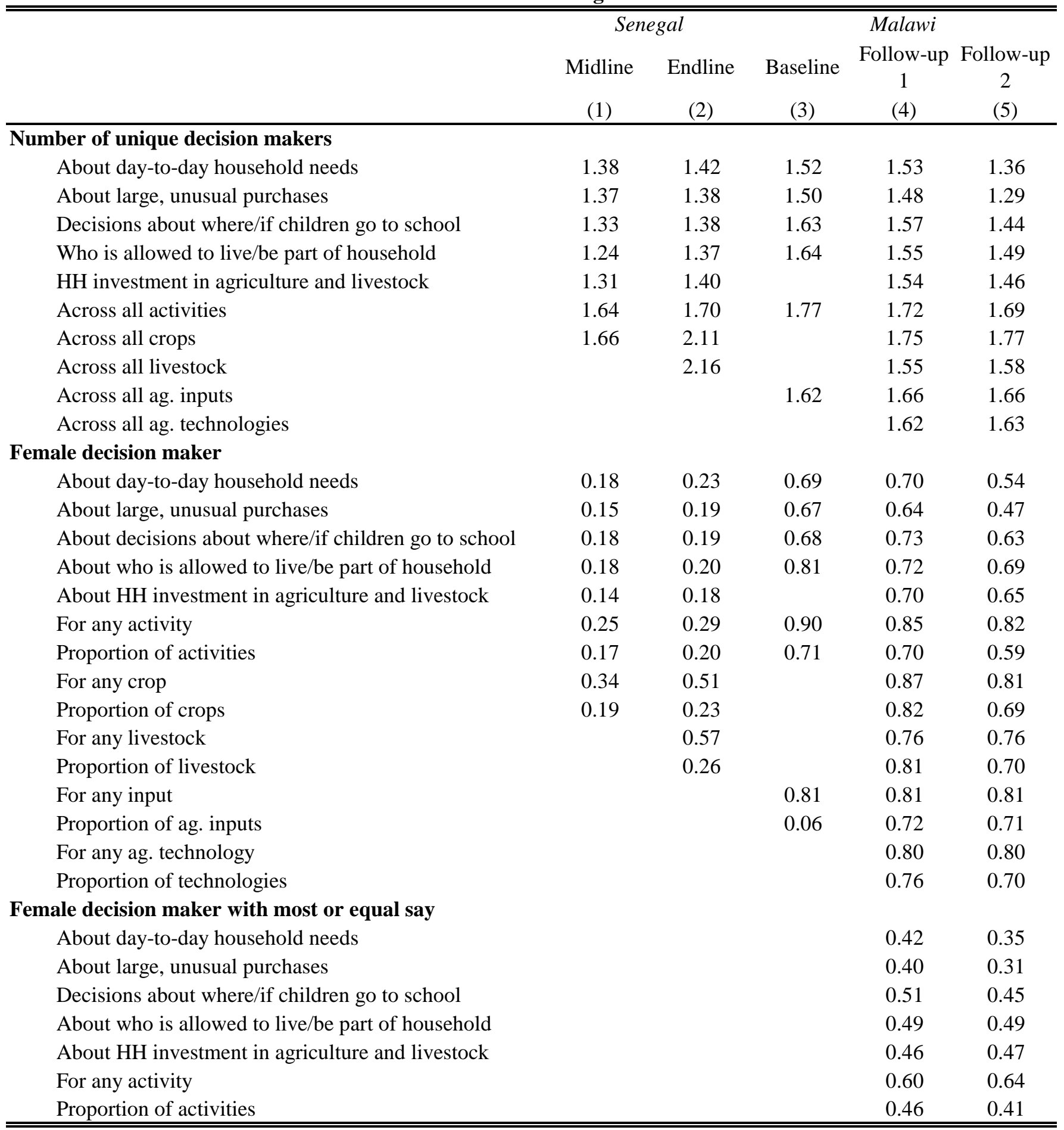

Notes: Author's calculation from Senegal midline and endline surveys, and Malawi baseline, follow-up 1, and follow-2 surveys. Malawi follow-up 2 sample excludes new farmers. 


\begin{tabular}{|c|c|c|c|c|c|c|c|c|}
\hline & \multicolumn{5}{|c|}{ Decisions about... } & \multicolumn{3}{|c|}{ Number of unique decision makers... } \\
\hline & $\begin{array}{c}\text { Day-to-day } \\
\text { household } \\
\text { needs }\end{array}$ & $\begin{array}{c}\text { Large, } \\
\text { unusual } \\
\text { purchases } \\
\text { (2) }\end{array}$ & $\begin{array}{c}\text { Decisions } \\
\text { about } \\
\text { where/if } \\
\text { children go } \\
\text { to school } \\
\text { (3) }\end{array}$ & $\begin{array}{c}\text { Who is } \\
\text { allowed to } \\
\text { live/be part } \\
\text { of } \\
\text { household } \\
\text { (4) }\end{array}$ & $\begin{array}{c}\mathrm{HH} \\
\text { investment } \\
\text { in } \\
\text { agriculture } \\
\text { and } \\
\text { livestock } \\
\text { (5) }\end{array}$ & $\begin{array}{l}\text { Across all } \\
\text { activities }\end{array}$ & $\begin{array}{c}\text { Across all } \\
\text { crops }\end{array}$ & $\begin{array}{l}\text { Across all } \\
\text { livestock }\end{array}$ \\
\hline \multicolumn{9}{|l|}{ Midline survey } \\
\hline \multirow[t]{2}{*}{ Household received FMP } & 0.001 & -0.051 & -0.011 & 0.001 & -0.066 & -0.038 & -0.190 & \\
\hline & $(0.993)$ & $(0.636)$ & $(0.918)$ & $(0.988)$ & $(0.387)$ & $(0.825)$ & $(0.270)$ & \\
\hline \multirow{2}{*}{ Household received FMP + Cash } & -0.141 & -0.191 & -0.018 & -0.053 & -0.078 & -0.222 & -0.524 & \\
\hline & $(0.151)$ & $(0.034)$ & $(0.850)$ & $(0.450)$ & $(0.317)$ & $(0.170)$ & $(0.005)$ & \\
\hline Observations & 239 & 239 & 235 & 239 & 239 & 239 & 239 & \\
\hline R-squared & 0.100 & 0.106 & 0.062 & 0.078 & 0.084 & 0.107 & 0.419 & \\
\hline Control mean & 1.430 & 1.443 & 1.338 & 1.253 & 1.354 & 1.722 & 1.873 & \\
\hline P-value: FMP = FMP + Cash & 0.150 & 0.120 & 0.936 & 0.428 & 0.878 & 0.192 & 0.025 & \\
\hline \multicolumn{9}{|l|}{ Endline survey } \\
\hline \multirow[t]{2}{*}{ Household received FMP } & 0.004 & -0.009 & -0.030 & 0.071 & -0.001 & -0.050 & -0.110 & -0.103 \\
\hline & $(0.951)$ & $(0.903)$ & $(0.680)$ & $(0.319)$ & $(0.993)$ & $(0.637)$ & $(0.417)$ & $(0.442)$ \\
\hline \multirow[t]{2}{*}{ Household received FMP + Cash } & -0.027 & -0.070 & -0.086 & 0.003 & -0.023 & -0.113 & 0.005 & -0.078 \\
\hline & $(0.715)$ & & $(0.205)$ & $(0.965)$ & $(0.769)$ & $(0.299)$ & $(0.974)$ & $(0.562)$ \\
\hline Observations & 598 & 598 & 592 & 598 & 598 & 598 & 598 & 598 \\
\hline R-squared & 0.158 & 0.154 & 0.187 & 0.203 & 0.161 & 0.106 & 0.171 & 0.187 \\
\hline Control mean & 1.407 & 1.387 & 1.386 & 1.327 & 1.387 & 1.734 & 2.131 & 2.176 \\
\hline P-value: $\mathrm{FMP}=\mathrm{FMP}+\mathrm{Cash}$ & 0.635 & 0.350 & 0.403 & 0.354 & 0.757 & 0.514 & 0.367 & 0.835 \\
\hline
\end{tabular}

Notes: Robust standard errors in parentheses are clustered by animateur. All regressions include stratification cell fixed effects. Columns 6,7 , and 8 additionally control for the number of relevant activities, crops, or animal types. 
Table 4: Impact of treatments on female decision making: Senegal

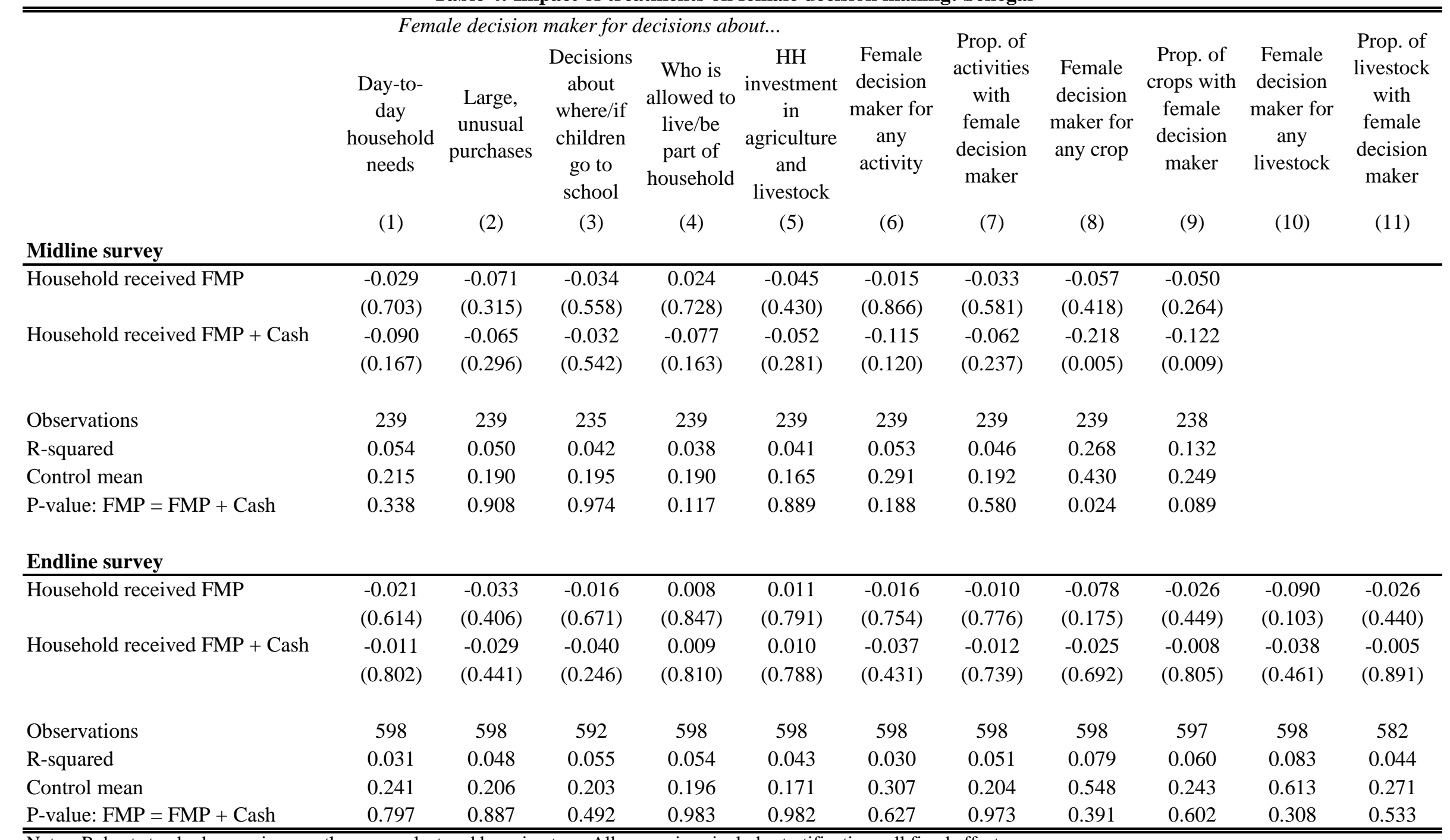

Notes: Robust standard errors in parentheses are clustered by animateur. All regressions include stratification cell fixed effects. 


\section{Table 5: Impact of transfers on number of decision makers: Malawi}

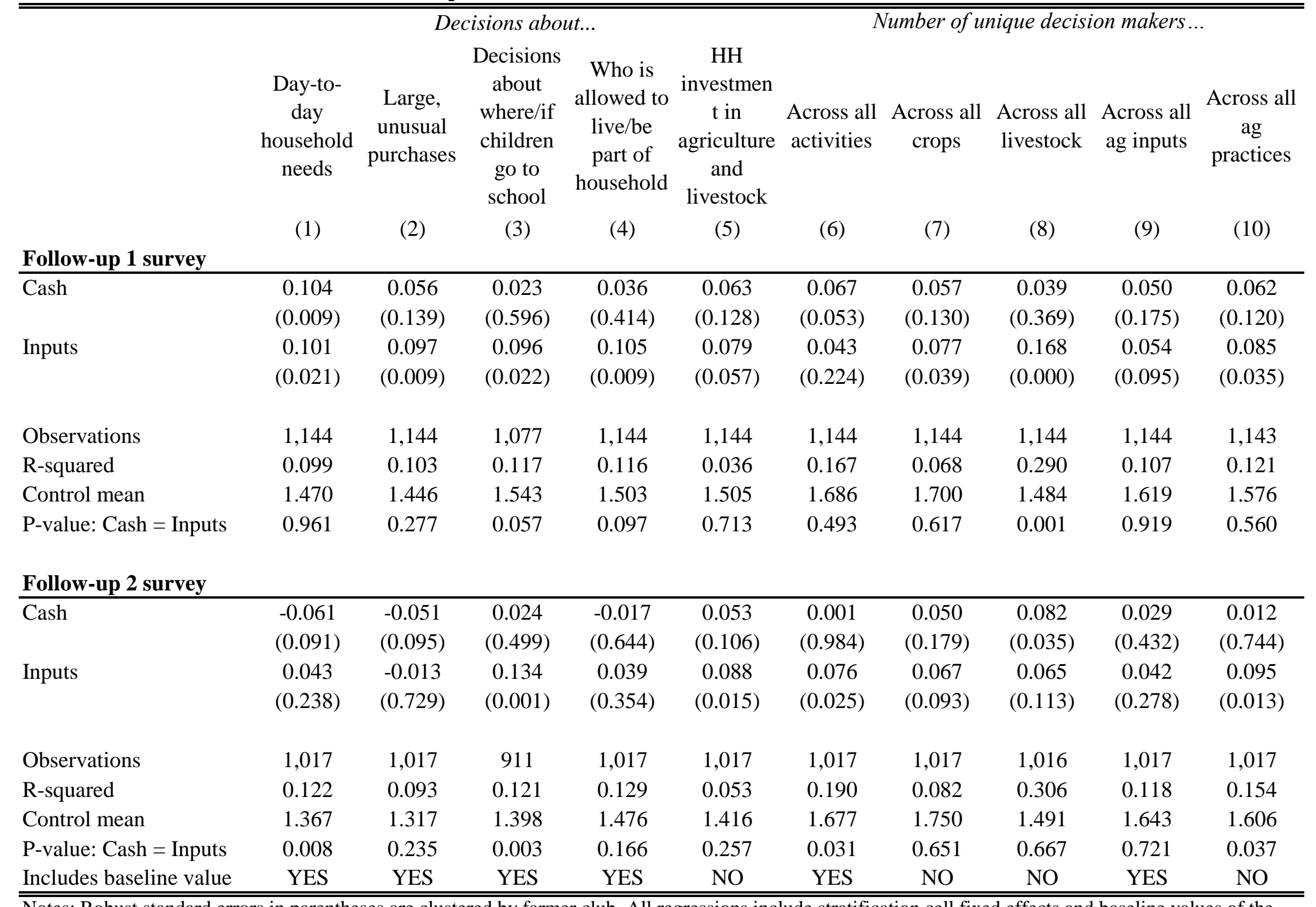

Notes: Robust standard errors in parentheses are clustered by farmer club. All regressions include stratification cell fixed effects and baseline values of the outcome variable (where indicated). Follow-up 2 regressions control for the phase 2 extension treatment. Columns 6 - 10 additionally control for the number of relevant activities, crops, animal types, inputs, or practices. 
Table 6: Impact of transfers on female decision making: Malawi

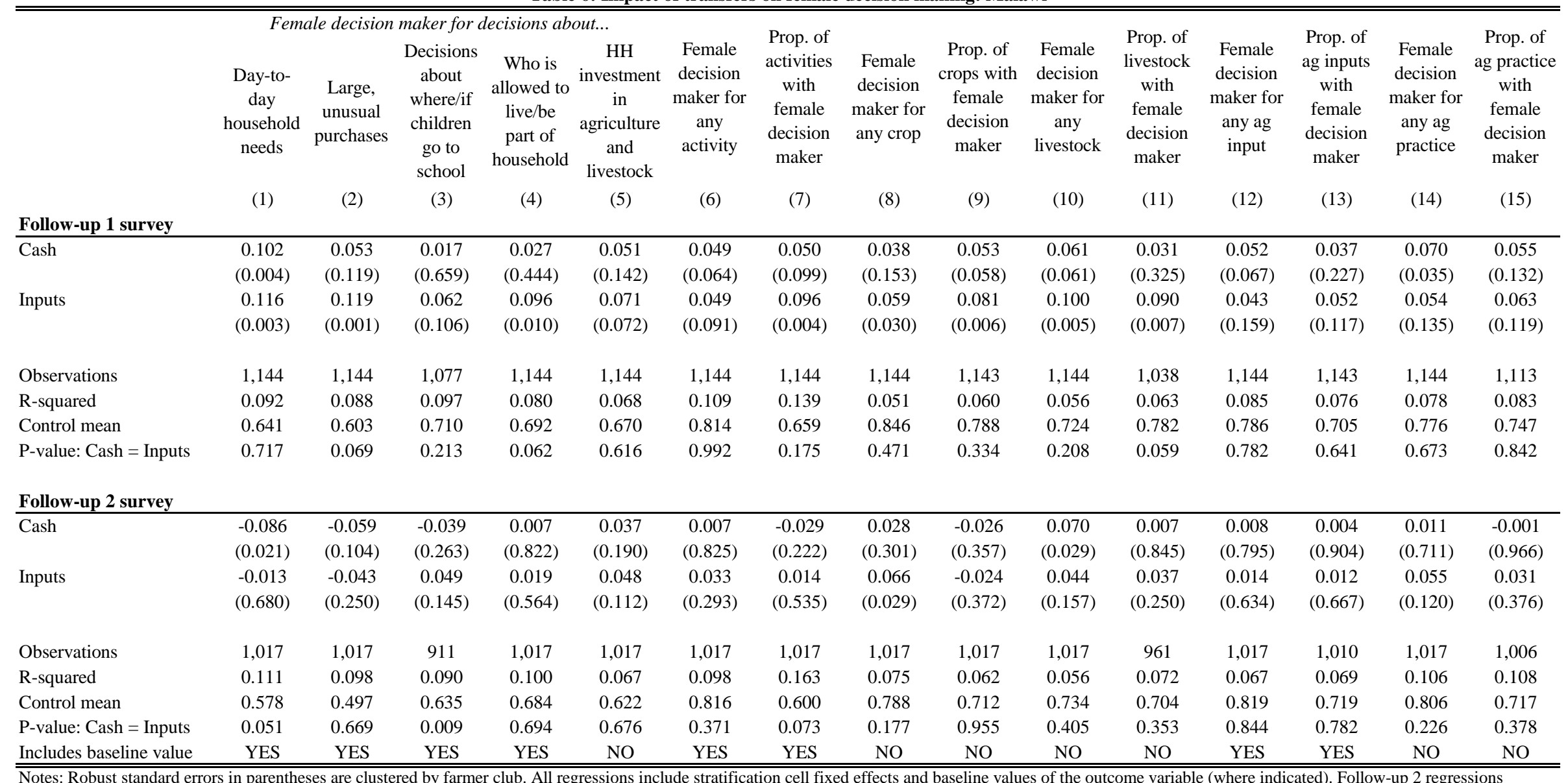

control for the phase 2 extension treatment. 
Female decision maker with most/equal say for decisions about...

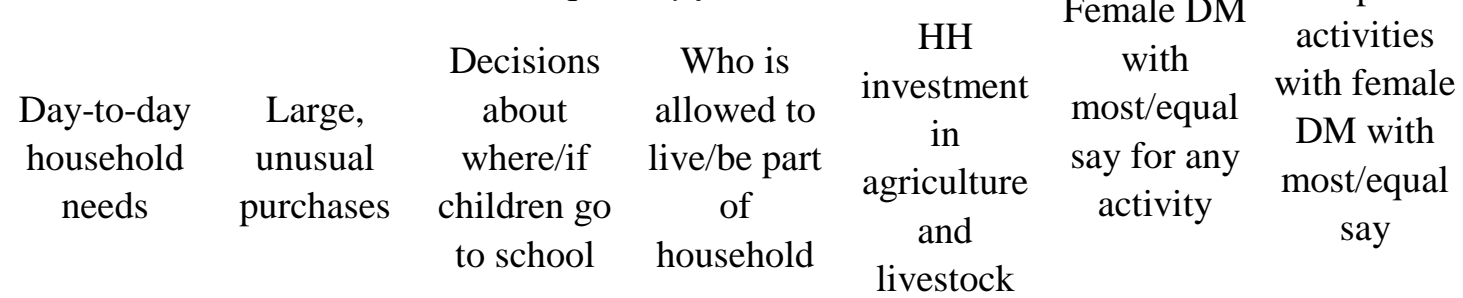
(1)

(2)

(3)

(4)

(5)

(6)

(7)

\begin{tabular}{|c|c|c|c|c|c|c|c|}
\hline Cash & $(0.001)$ & $(0.032)$ & $(0.618)$ & $(0.128)$ & $(0.049)$ & $(0.078)$ & $(0.040)$ \\
\hline \multirow[t]{2}{*}{ Inputs } & 0.069 & 0.090 & 0.039 & 0.071 & 0.055 & 0.050 & 0.068 \\
\hline & $(0.062)$ & $(0.013)$ & $(0.363)$ & $(0.105)$ & $(0.169)$ & $(0.214)$ & $(0.061)$ \\
\hline Observations & 1,144 & 1,144 & 1,077 & 1,144 & 1,144 & 1,144 & 1,144 \\
\hline Control mean & 0.378 & 0.362 & 0.490 & 0.446 & 0.424 & 0.557 & 0.417 \\
\hline P-value: Cash = Inputs & 0.224 & 0.696 & 0.645 & 0.806 & 0.668 & 0.627 & 0.956 \\
\hline \multicolumn{8}{|l|}{ Follow-up 2 survey } \\
\hline Inputs & $(0.585)$ & $(0.783)$ & $(0.543)$ & $(0.603)$ & $(0.450)$ & $(0.662)$ & $(0.677)$ \\
\hline Observations & 1,017 & 1,017 & 911 & 1,017 & 1,017 & 1,017 & 1,017 \\
\hline R-squared & 0.037 & 0.049 & 0.067 & 0.053 & 0.056 & 0.063 & 0.054 \\
\hline Control mean & 0.363 & 0.294 & 0.446 & 0.484 & 0.444 & 0.641 & 0.404 \\
\hline P-value: Cash = Inputs & 0.811 & 0.553 & 0.595 & 0.887 & 0.489 & 0.994 & 0.958 \\
\hline Includes baseline value & $\mathrm{NO}$ & $\mathrm{NO}$ & $\mathrm{NO}$ & $\mathrm{NO}$ & $\mathrm{NO}$ & $\mathrm{NO}$ & $\mathrm{NO}$ \\
\hline
\end{tabular}

Notes: Robust standard errors in parentheses are clustered by farmer club. All regressions include stratification cell fixed effects.

Follow-up 2 regressions control for the phase 2 extension treatment. 
Table 8: Impact of transfers and extension on decisionmaking: Malawi

\begin{tabular}{|c|c|c|c|c|c|c|c|c|c|c|}
\hline \multirow{3}{*}{ Follow-up 1 survey } & \multicolumn{5}{|c|}{ Number of unique decision makers across all... } & \multicolumn{5}{|c|}{ Proportion of ... with female decision maker } \\
\hline & $\begin{array}{c}\text { Activities } \\
\text { (1) }\end{array}$ & $\begin{array}{c}\text { Crops } \\
\text { (2) }\end{array}$ & $\begin{array}{c}\text { Livestock } \\
\text { (3) }\end{array}$ & $\begin{array}{c}\text { Ag inputs } \\
\text { (4) }\end{array}$ & $\begin{array}{c}\mathrm{Ag} \\
\text { practices } \\
(5)\end{array}$ & $\begin{array}{c}\text { Activities } \\
\text { (6) }\end{array}$ & $\begin{array}{c}\text { Crops } \\
\text { (7) }\end{array}$ & $\begin{array}{c}\text { Livestock } \\
\text { (8) }\end{array}$ & $\begin{array}{c}\text { Ag inputs } \\
\text { (9) }\end{array}$ & $\begin{array}{c}\mathrm{Ag} \\
\text { practices } \\
(10)\end{array}$ \\
\hline & & & & & & & & & & \\
\hline Transfer only & $\begin{array}{c}-0.073 \\
(0.130)\end{array}$ & $\begin{array}{c}0.014 \\
(0.822)\end{array}$ & $\begin{array}{c}0.061 \\
(0.358)\end{array}$ & $\begin{array}{c}-0.040 \\
(0.397)\end{array}$ & $\begin{array}{c}0.009 \\
(0.895)\end{array}$ & $\begin{array}{c}0.003 \\
(0.948)\end{array}$ & $\begin{array}{c}0.009 \\
(0.814)\end{array}$ & $\begin{array}{c}0.014 \\
(0.750)\end{array}$ & $\begin{array}{c}-0.016 \\
(0.684)\end{array}$ & $\begin{array}{c}-0.045 \\
(0.368)\end{array}$ \\
\hline Extension only & $\begin{array}{l}-0.222 \\
(0.000)\end{array}$ & $\begin{array}{l}-0.088 \\
(0.192)\end{array}$ & $\begin{array}{l}-0.060 \\
(0.493)\end{array}$ & $\begin{array}{l}-0.102 \\
(0.041)\end{array}$ & $\begin{array}{l}-0.026 \\
(0.709)\end{array}$ & $\begin{array}{l}-0.092 \\
(0.073)\end{array}$ & $\begin{array}{l}-0.043 \\
(0.402)\end{array}$ & $\begin{array}{l}-0.034 \\
(0.560)\end{array}$ & $\begin{array}{l}-0.042 \\
(0.407)\end{array}$ & $\begin{array}{l}-0.080 \\
(0.205)\end{array}$ \\
\hline Both & $\begin{array}{c}0.004 \\
(0.919)\end{array}$ & $\begin{array}{c}0.047 \\
(0.198)\end{array}$ & $\begin{array}{c}0.093 \\
(0.077)\end{array}$ & $\begin{array}{c}0.059 \\
(0.111)\end{array}$ & $\begin{array}{c}0.110 \\
(0.011)\end{array}$ & $\begin{array}{c}0.065 \\
(0.082)\end{array}$ & $\begin{array}{c}0.084 \\
(0.008)\end{array}$ & $\begin{array}{c}0.072 \\
(0.036)\end{array}$ & $\begin{array}{c}0.066 \\
(0.072)\end{array}$ & $\begin{array}{c}0.088 \\
(0.032)\end{array}$ \\
\hline Observations & 1,144 & 1,144 & 1,144 & 1,144 & 1,143 & 1,144 & 1,143 & 1,038 & 1,143 & 1,113 \\
\hline R-squared & 0.176 & 0.069 & 0.285 & 0.111 & 0.124 & 0.141 & 0.063 & 0.062 & 0.080 & 0.094 \\
\hline Control mean & 1.735 & 1.721 & 1.531 & 1.637 & 1.571 & 0.681 & 0.788 & 0.786 & 0.704 & 0.750 \\
\hline P-value: Transfer $=$ Extensio & 0.001 & 0.048 & 0.074 & 0.126 & 0.479 & 0.018 & 0.187 & 0.327 & 0.532 & 0.493 \\
\hline P-value: Transfer $=$ Both & 0.051 & 0.498 & 0.536 & 0.013 & 0.046 & 0.067 & 0.023 & 0.114 & 0.016 & 0.001 \\
\hline P-value: Extension $=$ Both & 0.000 & 0.019 & 0.043 & 0.000 & 0.016 & 0.000 & 0.006 & 0.053 & 0.017 & 0.003 \\
\hline \multicolumn{11}{|l|}{ Follow-up 2 survey } \\
\hline Transfer only & $\begin{array}{c}-0.005 \\
(0.917)\end{array}$ & $\begin{array}{c}0.056 \\
(0.217)\end{array}$ & $\begin{array}{c}0.081 \\
(0.048)\end{array}$ & $\begin{array}{c}0.021 \\
(0.710)\end{array}$ & $\begin{array}{c}0.057 \\
(0.312)\end{array}$ & $\begin{array}{c}0.034 \\
(0.286)\end{array}$ & $\begin{array}{c}-0.010 \\
(0.558)\end{array}$ & $\begin{array}{c}0.114 \\
(0.012)\end{array}$ & $\begin{array}{c}-0.004 \\
(0.744)\end{array}$ & $\begin{array}{c}0.059 \\
(0.230)\end{array}$ \\
\hline Extension only & $\begin{array}{c}-0.088 \\
(0.142)\end{array}$ & $\begin{array}{c}0.052 \\
(0.438)\end{array}$ & $\begin{array}{c}0.098 \\
(0.131)\end{array}$ & $\begin{array}{c}0.062 \\
(0.341)\end{array}$ & $\begin{array}{c}0.023 \\
(0.723)\end{array}$ & $\begin{array}{c}0.076 \\
(0.044)\end{array}$ & $\begin{array}{c}-0.011 \\
(0.528)\end{array}$ & $\begin{array}{c}0.181 \\
(0.001)\end{array}$ & $\begin{array}{c}0.002 \\
(0.846)\end{array}$ & $\begin{array}{c}0.064 \\
(0.245)\end{array}$ \\
\hline Both & $\begin{array}{c}0.005 \\
(0.897)\end{array}$ & $\begin{array}{c}0.098 \\
(0.025)\end{array}$ & $\begin{array}{c}0.141 \\
(0.000)\end{array}$ & $\begin{array}{c}0.094 \\
(0.049)\end{array}$ & $\begin{array}{c}0.063 \\
(0.132)\end{array}$ & $\begin{array}{c}0.011 \\
(0.678)\end{array}$ & $\begin{array}{c}-0.005 \\
(0.659)\end{array}$ & $\begin{array}{c}0.077 \\
(0.032)\end{array}$ & $\begin{array}{c}-0.001 \\
(0.960)\end{array}$ & $\begin{array}{c}0.023 \\
(0.527)\end{array}$ \\
\hline Observations & 1,017 & 1,017 & 1,016 & 1,017 & 1,017 & 1,017 & 1,017 & 961 & 968 & 1,006 \\
\hline R-squared & 0.188 & 0.084 & 0.309 & 0.122 & 0.150 & 0.163 & 0.047 & 0.079 & 0.045 & 0.108 \\
\hline Control mean & 1.685 & 1.746 & 1.452 & 1.619 & 1.619 & 0.584 & 0.016 & 0.653 & 0.013 & 0.711 \\
\hline P-value: Transfer $=$ Extensio & 0.069 & 0.944 & 0.774 & 0.306 & 0.486 & 0.150 & 0.152 & 0.102 & 0.150 & 0.896 \\
\hline P-value: Transfer $=$ Both & 0.809 & 0.291 & 0.118 & 0.115 & 0.889 & 0.469 & 0.722 & 0.354 & 0.937 & 0.425 \\
\hline P-value: Extension = Both & 0.066 & 0.465 & 0.505 & 0.581 & 0.494 & 0.102 & 0.387 & 0.042 & 0.251 & 0.429 \\
\hline Includes baseline value & YES & $\mathrm{NO}$ & $\mathrm{NO}$ & YES & $\mathrm{NO}$ & YES & $\mathrm{NO}$ & $\mathrm{NO}$ & YES & $\mathrm{NO}$ \\
\hline
\end{tabular}

Notes: Robust standard errors in parentheses are clustered by farmer club. All regressions include stratification cell fixed effects and baseline values of the outcome variable (where indicated). Follow-up 2 regressions control for the phase 2 extension treatment. 


\section{Appendix 1: Outcome variable construction}

\section{A. Senegal}

\section{Decision making about activities:}

At midline and endline respondents were asked to select, from the household roster, the household members who participated in decisions about the following activities:

- Day-to-day household needs

- Large, unusual purchases

- Decisions about where/if children go to school (asked only if household included school-age children)

- Who is allowed to live in/be part of household

- Household investment in agriculture and livestock

Respondents could list up to five household members. ${ }^{1}$ From these five questions we create the following variables:

1. Number of decision makers for each category

2. Total number of unique decision makers across all five categories

3. For each category: whether or not a female is listed as a decision maker $(0 / 1)$

4. Across all five categories: whether or not any female is listed in any category

5. Across all five categories: the proportion of activities (either four or five depending on presence of children) for which a female is listed as a decision maker

\section{Decision making about crops:}

At midline and endline, respondents were asked, for each crop that they report planting, to select, from the household roster, the household members who made decisions about that crop. They could list up to two household members. The text of the questions was as follows:

Which household member(s) makes decisions about [...]? (This includes all decisions including those related to planting, inputs, and sales).

From these crop-level questions, we create the following variables:

1. Total number of unique decision makers across all crops grown

2. Across all crops: whether or not any female is listed for any crop

3. Across all crops: the proportion of crops grown by household for which a female is listed as a decision maker

Decision making about livestock:

\footnotetext{
${ }^{1}$ If more than one member was listed, respondents were asked whether all decision makers have equal say in this decision or if someone has more say than others. If someone has more say, they are asked to list up to two household members with the most say. However, because, in the Senegal data, very few women were reported to have most or equal say in decisions, we do not use this information in our analysis of the Senegal data.
} 
At endline only, respondents were asked, for each type of animal that they report owning, to select, from the household roster, the household members who made decisions about that type of animal. They could list up to two household members. The text of the questions was as follows:

Which household members makes decisions about [...]? (This includes all decisions, including purchase, care, and sales).

From these animal type-level questions, we create the following variables:

1. Total number of unique decision makers across all animal types owned

2. Across all animal types owned: whether or not any female is listed for any animal type

3. Across all animal types owned: the proportion of animal types owned by household for which a female is listed as a decision maker

\section{B. Malawi}

Decision making about activities (baseline):

At baseline respondents were asked to select, from the household roster, the household members who participated in decisions about the following activities:

- Day-to-day household needs

- Large, unusual purchases

- Decisions about where/if children go to school (asked only if household included school-age children)

- Who is allowed to live in/be part of household

Respondents could list up to two household members. From these five questions we create the following variables:

1. Number of decision makers for each category

2. Total number of unique decision makers across all four categories

3. For each category: whether or not a female is listed as a decision maker $(0 / 1)$

4. Across all four categories: whether or not any female is listed in any category

5. Across all four categories: the proportion of activities (either three or four depending on presence of children) for which a female is listed as a decision maker

Decision making about activities (follow-up 1 and follow-up 2):

In both follow-ups respondents were asked to select, from the household roster, the household members who participated in decisions about the following activities:

- Day-to-day household needs

- Large, unusual purchases

- Decisions about where/if children go to school (asked only if household included school-age children)

- Who is allowed to live in/be part of household

- Household investment in agriculture and livestock 
Respondents could list up to three household members. If more than one member was listed, respondents were asked whether all decision makers have equal say in this decision or if someone has more say than others. If someone has more say, they are asked to list household member with the most say. From these five questions we create the following variables:

1. Number of decision makers for each category

2. Total number of unique decision makers across all five categories

3. For each category: whether or not a female is listed as a decision maker $(0 / 1)$

4. Across all five categories: whether or not any female is listed in any category

5. Across all five categories: the proportion of activities (either four or five depending on presence of children) for which a female is listed as a decision maker

6. For each category: whether or not a female is listed a decision maker with most or equal say $(0 / 1)$

7. Across all five categories: whether or not any female is listed in any category as decision maker with most or equal day

8. Across all five categories: the proportion of activities (either four or five depending on presence of children) for which a female is listed as a decision maker with most or equal say

Decision making about crops:

At follow-up 1 and follow-up 2 only, ${ }^{2}$ respondents were asked, for each crop, to select, from the household roster, the household members who made decisions about that crop. They could list up to two household members. The text of the questions was as follows:

Which household member(s) makes decisions about [...]? (This includes all decisions including those related to planting, inputs, and sales).

From these crop-level questions, we create the following variables:

1. Total number of unique decision makers across all crops grown

2. Across all crops: whether or not any female is listed for any crop

3. Across all crops: the proportion of crops grown by household for which a female is listed as a decision maker

\section{Decision making about livestock:}

At follow-up 1 and follow-up 2 only, respondents were asked, for each type of animal, to select, from the household roster, the household members who made decisions about that type of animal. They could list up to two household members. The text of the questions was as follows:

Which household members makes decisions about [...]? (This includes all decisions, including purchase, care, and sales).

From these animal type-level questions, we create the following variables:

\footnotetext{
2 These questions were asked in a different way at baseline, so we do not include them in our analyses.
} 
1. Total number of unique decision makers across all animal types owned

2. Across all animal types owned: whether or not any female is listed for any animal type

3. Across all animal types owned: the proportion of animal types owned by household for which a female is listed as a decision maker

\section{Decision making about agricultural inputs:}

At baseline, follow-up 1, and follow-up 2, respondents were asked, for each input listed, to select, from the household roster, the household members who made decisions about that input. They could list up to two household members. The text of the questions was as follows:

Which household member(s) made decisions about using [...]?

The inputs listed on the survey were: rent for horses/oxen for ploughing, seeds, fertilizer, manure, pesticides, hired labor for crop production, hired labor for livestock, and free response for other categories.

From these input-level questions, we create the following variables:

1. Total number of unique decision makers across all input types used in the last season

2. Across all input types used in the past season: whether or not any female is listed for any input

3. Across all input types used in the past season: the proportion of input types used by the household in the last season for which a female is listed as a decision maker

\section{Decision making about agricultural practices:}

At follow-up 1 and follow-up 2 only, ${ }^{3}$ respondents were asked, for each practice listed, to select, from the household roster, the household members who made decisions about that practice. They could list up to two household members. The text of the questions was as follows:

Which household member(s) made decisions about using [...]?

The practices listed on the survey were: Basin planting, no till/minimum soil disturbance, crop cover/residue retention, use of box ridges, crop rotation, inter/mixed cropping with legume, one seed per station, agro-forestry, manure application, irrigation, two rows per ridge.

From these practice-level questions, we create the following variables:

1. Total number of unique decision makers across all practice types used in the last season

2. Across all practice types used in the past season: whether or not any female is listed for any practice

3. Across all practice types used in the past season: the proportion of practice types used by the household in the last season for which a female is listed as a decision maker

\footnotetext{
${ }^{3}$ This question was asked in a different way at baseline, so we do not use the baseline data.
} 
